\title{
Boguslawa Bek-Gaik
}

AGH Akademia Górniczo-Hutnicza w Krakowie

e-mail: bbek@zarz.agh.edu.pl

ORCID: 0000-0001-6646-7808

\author{
Anna Surowiec \\ AGH Akademia Górniczo-Hutnicza w Krakowie \\ e-mail: asurow2@zarz.agh.edu.pl \\ ORCID: 0000-0001-6407-7136
}

\section{RAPORTOWANIE ZINTEGROWANE W PRAKTYCE POLSKICH SPÓLEK - PRÓBA OCENY JAKOŚCI UJAWNIEŃ}

\section{INTEGRATED REPORTING IN THE PRACTICE OF POLISH COMPANIES - AN ATTEMPT OF ASSESSMENT OF THE DISCLOSURES QUALITY}

DOI: $10.15611 /$ pn.2019.11.14

JEL Classification: M40

Streszczenie: Raport zintegrowany jest obecnie uważany za najdoskonalszą formę raportowania informacji niefinansowych. Jego zasadnicze cele stanowią połączenie informacji finansowych i niefinansowych na temat organizacji w jednym dokumencie oraz podniesienie efektywności komunikowania zewnętrznym interesariuszom informacji o tworzeniu wartości przez organizacje. Celem artykułu jest próba oceny jakości ujawnień w praktyce raportowania zintegrowanego polskich spółek w latach 2013-2017. W części empirycznej, wykorzystując analizę treści (content analysis) z zastosowaniem ważonego indeksu ujawnień (weighted disclosure index), przeprowadzono badanie jakości raportów zintegrowanych opracowanych przez 20 grup kapitałowych w rozpatrywanym okresie. Wyniki badań wskazują na stopniowe pozytywne zmiany w odniesieniu do zarówno liczby publikowanych raportów, jak i jakości niektórych obszarów ujawnień w publikowanych raportach. Pewne elementy raportów wymagają jednak poprawy i udoskonalenia.

Słowa kluczowe: raport zintegrowany, sprawozdawczość finansowa, sprawozdawczość niefinansowa, informacje finansowe, informacje niefinansowe.

Summary: The integrated report is currently considered the most perfect form of reporting non-financial information. Its main purpose is to combine financial and non-financial information about organizations in one document and to increase the effectiveness of information communication about value creation by organizations to external stakeholders. The purpose of the article is an attempt to assess the quality of disclosures in the practice of 
integrated reporting of Polish companies between 2013 and 2017. In the empirical part of the article, using content analysis and weighted disclosure index, the quality of integrated reports prepared by 20 capital groups during the examined period, was examined. Research results indicate gradual positive changes both in terms of the number of published reports and the quality of some areas of disclosure in published reports. However, certain elements of reports require improvements and advancement.

Keywords: integrated report, financial reporting, non-financial reporting, financial information, non-financial information.

\section{Wstęp}

W związku z dynamicznym rozwojem nurtu informacji niefinansowych w ostatnim okresie można zaobserwować rosnącą złożoność i obszerność różnych sprawozdań organizacji, stanowiących próbę połączenia ujawnień o tematyce społecznej i ekologicznej z ujawnieniami finansowymi. W przeciwieństwie do wcześniejszych ujawnień na temat kwestii społecznych i ekologicznych prezentowanych w ramach sprawozdań rocznych, w których informacje z tych obszarów nie były zintegrowane $\mathrm{z}$ informacjami o charakterze finansowym, nowe formy sprawozdań dążą do zintegrowania informacji nt. kwestii społecznych, ekologicznych, finansowych i dotyczących ładu korporacyjnego [Dey, Burns 2010].

Niewątpliwie najbardziej rozwiniętą formą sprawozdawczą przedstawiającą informacje finansowe i niefinansowe $\mathrm{w}$ jednym dokumencie jest raport zintegrowany ${ }^{1}$ (IR - integrated report). Sprawozdawczość zintegrowana szybko zyskała znaczącą pozycję i uznanie od czasu sformułowania jej założeń w 2010 r. przez Międzynarodowy Komitet ds. Sprawozdawczości Zintegrowanej (IIRC - International Integrated Reporting Committee), przemianowany następnie na Międzynarodową Radę ds. Sprawozdawczości Zintegrowanej (International Integrated Reporting Council).

Chociaż sprawozdawczość zintegrowana stanowi relatywnie nowy obszar raportowania organizacji, badania zarówno teoretyczne, jak i praktyczne dotyczące tego zagadnienia szybko się rozwinęły². Nadal jednak jest to temat budzący wiele kontrowersji i wciąż nieposiadający jednolitej formy sprawozdawczej.

Sprawozdawczość zintegrowana w swoim podstawowym założeniu miała przedstawiać w jednym dokumencie ujawnienia finansowe i niefinansowe dotyczące dokonań organizacji. Ponadto raportowanie zintegrowane miało przede wszystkim in-

${ }^{1}$ W literaturze przedmiotu określenie integrated reporting thumaczone jest również jako sprawozdawczość zintegrowana.

2 Por. prace takich autorów, jak: Dragu, Tudor-Tiron [2013], Eccles, Krzus, Tapscott [2010], Saltzman [2011], Climate Change and Sustainability [2011], Frias-Aceituno, Rodríguez-Ariza, García-Sanchez [2013], Krasodomska [2012], Maroun, Solomon [2012], Michalczuk, Mikulska [2014], Rensburg, Botha [2014], Samelak [2013], Stubbs, Higgins [2014], Świderska, Bek-Gaik [2016], Walińska [2015], Bek-Gaik [2015], Bek-Gaik, Rymkiewicz [2015], a także Bek-Gaik, Rymkiewicz [2016]. 
formować o zdolności organizacji do tworzenia i utrzymywania wartości w krótkim, średnim i długim okresie, a jednym z jego zasadniczych celów jest wprowadzenie zmian do procesów sprawozdawczych organizacji uwzględniających wszystkie aspekty tworzenia wartości - zarówno finansowe, jak i niefinansowe. IR zatem to okresowy raport/sprawozdanie na temat historii tworzenia wartości.

Aby umożliwić holistyczne zrozumienie różnych typów ujawnianych informacji, niektóre organizacje publikują swoje raporty zintegrowane w celu prezentacji sposobu wykorzystania i wzajemnych zależności swoich różnorodnych zasobów (finansowych, produkcyjnych, ludzkich, intelektualnych, społecznych i naturalnych) oraz efektów swojej działalności (produkty i usługi, wpływ na środowisko naturalne, efekty społeczne itp.). Ujawniona informacja może być zatem wykorzystana do poprawy długookresowej oceny rentowności firmy, a także do zidentyfikowania ewentualnych niepewności w przyszłości. Jak stwierdzają R. Eccles i in. [2010], firmy powinny sporządzać raporty zintegrowane, ponieważ dokumenty te odgrywają kluczową rolę w legitymizacji organizacji w zakresie społecznej odpowiedzialności biznesu (CSR) oraz zapewniają transparentną sprawozdawczość.

Praktyka sprawozdawczości zintegrowanej jest bardzo zróżnicowana i znajduje się we wczesnym stadium rozwoju. Obecnie można zaobserwować stopniową akceptację tej formy sprawozdawczej przez organizacje i interesariuszy. Stale wzrasta również liczba badań naukowych dotyczących sprawozdawczości zintegrowanej, mających na celu rozpoznanie jej praktyki oraz kosztów i korzyści związanych z jej wprowadzeniem.

W niniejszym artykule autorki podjęły próbę zbadania zakresu i jakości ujawnień informacji w sprawozdaniach zintegrowanych polskich spółek. Badania przeprowadzono na próbie 60 raportów zintegrowanych od 2013 roku, czyli od momentu wprowadzenia przez IIRC Międzynarodowej Struktury Ramowej Sprawozdawczości Zintegrowanej (International Integrated Reporting Framework-IR Framework).

\section{Jakość informacji i metody jej pomiaru}

Pojęcie jakości informacji w literaturze przedmiotu nie zostało jednoznacznie zdefiniowane i jest różnie interpretowane przez teoretyków i praktyków. Wynika to z faktu, że jakość informacji może być inaczej interpretowana przez poszczególnych odbiorców informacji. Ponadto w literaturze stosowane są także terminy ,jakość danych" i ,jakość informacji”, niekiedy używane zamiennie [Helfert i in. 2009]. Jednakże jakość danych odnoszona jest do ogólnej definicji jakości [Wang, Strong 1996], rozumianej jako całość cech produktu, która ma zdolność zaspokajania określonych lub dorozumianych potrzeb [ISO 2000]. Natomiast jakość informacji w literaturze rozpatrywana jest często z perspektywy jakości spełniającej oczekiwania odbiorców. M. Gustavsson i C. Wänström [2009] definiują jakość informacji jako zdolność do zaspokojenia stwierdzonych i dorozumianych potrzeb konsumenta informacji. Określenie „konsument informacji” odnosi się do użytkownika. Na jakość 
informacji może więc wpływać użytkownik. Podejście to akcentuje znaczenie informacji w aspekcie użytkowym, czyli praktycznej przydatności informacji dla użytkownika.

W literaturze wskazywane są różne cechy jakościowe informacji. Jakość informacji definiowana jest $\mathrm{w}$ aspektach: dostępności, interpretowalności, przydatności, integralności, rzetelności, niezawodności czy użyteczności [Bovee i in. 2003; Kahn i in. 2002]. Y. Wang i D. Strong [1996 ] określili cztery wymiary cech jakościowych informacji:

- wewnętrzny (wiarygodność, dokładność, obiektywność, reputacja),

- kontekstu (wartość dodana, użyteczność, aktualność, kompletność, odpowiednia ilość danych),

- reprezentacji (interpretowalność, łatwość zrozumienia, spójna reprezentacja, zwięzłość),

- dostępności (dostęp, bezpieczeństwo dostępu).

Z punktu widzenia sprawozdawczości biznesowej istotne jest wyodrębnienie informacji finansowych i niefinansowych. Jakość informacji finansowych opisywana jest przez różne atrybuty jakości, wśród których najczęściej wymieniane są dwie fundamentalne cechy [IASB 2018]: istotność i wierne przedstawienie. Użyteczność cech fundamentalnych zwiększają komplementarne z nimi cechy dodatkowe, opisywane przez porównywalność, weryfikowalność, terminowość i zrozumiałość.

Należy podkreślić, że nie ma jednej powszechnie przyjętej definicji pojęcia „informacje niefinansowe” i ich klasyfikacji. Są one jednak od lat przywoływane w literaturze, a w związku z wprowadzeniem Dyrektywy 2014/95/UE [2014] można przypuszczać, że ich znaczenie i liczba poświęconych im publikacji wzrośnie (por. m.in. [Kazirod 2002; Kabalski 2005; Marcinkowska 2006; Świderska 2007; Roszkowska 2008; Michalczuk 2009; Wrona 2009; Wasilewska 2010; Stępień 2010; Sobczyk 2012; Kędzierska-Bujak 2013; Mućko, Hońko 2013; Szadziewska 2013; Karmańska 2014; Walińska i in. 2015; Walińska i in. 2016]). Propozycję definicji informacji niefinansowych przedstawia J. Krasodomska [2014, s. 28]. Według tej autorki ,pojęcie informacje niefinansowe obejmuje wszelkie informacje (opisowe lub liczbowe, przy czym niekoniecznie wyrażone w mierniku pieniężnym), publikowane (obowiązkowo lub dobrowolnie) w ramach rocznego raportu przedsiębiorstwa, poza sprawozdaniem finansowym oraz opinią i raportem biegłego rewidenta". Informacje niefinansowe mogą mieć charakter narracyjny, ale także liczbowy [Sobańska 2007].

Problematyka pomiaru i oceny jakości informacji jest zagadnieniem złożonym, zwłaszcza w odniesieniu do informacji narracyjnych ${ }^{3}$. Klasyfikację metod analizy informacji narracyjnych przedstawili V. Beattie, B. McInnes i S. Fearnley [2004],

${ }^{3} \mathrm{~W}$ polskiej literaturze przedmiotu zagadnienie metod pomiaru jakości ujawnień opisywali m.in. Mućko [2018] i Dyduch [2018]. 
wyodrębniając metody subiektywne (bazujące na ankietach oceny jakości sprawozdań) oraz semiobiektywne (zawierające elementy obiektywizujące ocenę (rys. 1)).

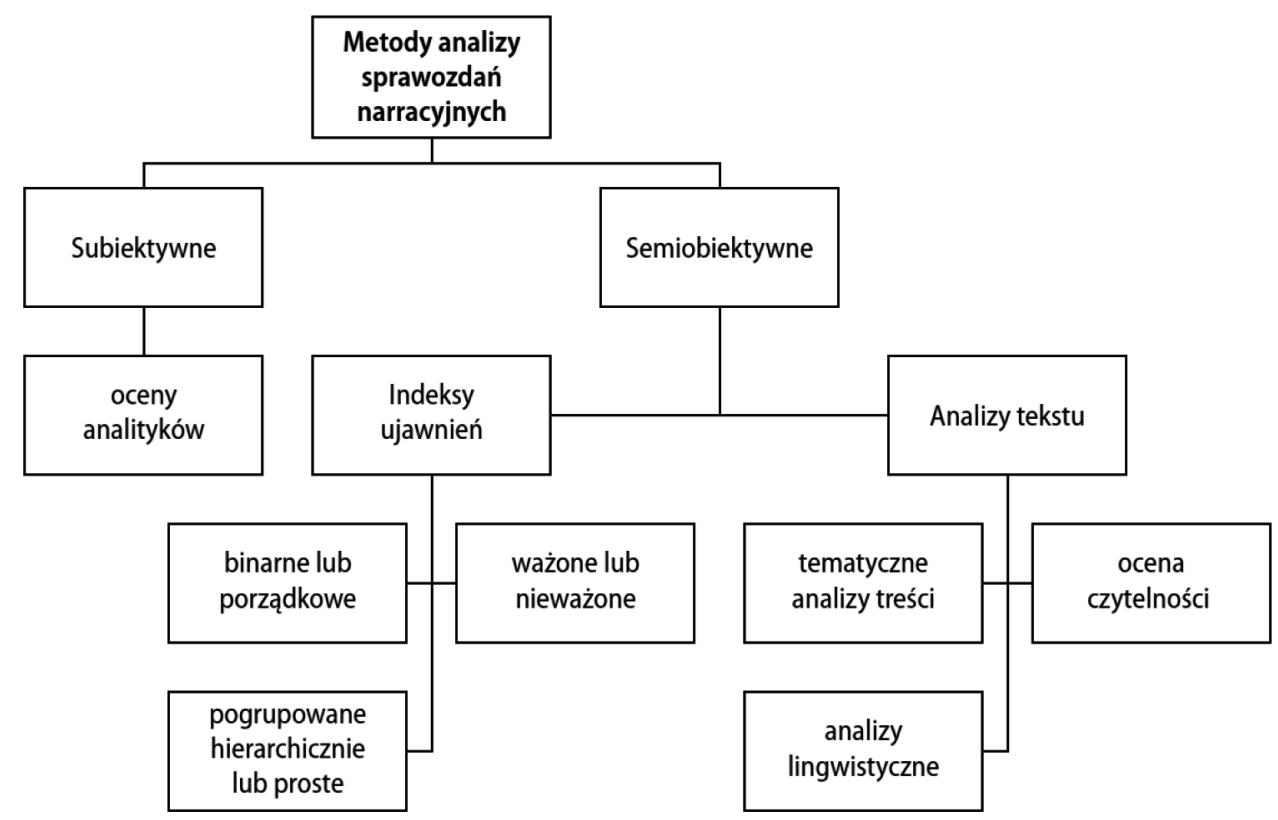

Rys. 1. Klasyfikacja metod pomiaru jakości ujawnień narracyjnych Źródło: [Beattie i in. 2004], za [ Mućko 2018].

W literaturze przedmiotu jako praktyczne metody pomiaru jakości informacji stosowane są:

- analiza stopnia wypełnienia wytycznych ujawnień [Razaee, Tuo 2019];

- metoda scoringowa [Chakroun, Hussainey 2014; Garcia-Sanchez i in. 2019];

- indeksy ujawnień [Czajor, Michalak 2016; Alotaibi, Hussainey 2016; Li, Liu 2018; Katmon i in. 2018; Gerwanski i in. 2018; Helfaya, Whittington 2018];

- analiza treści [Elshandidy, Neri, Guo 2018; Leopizzi i in. 2019; Leitoniene, Sapkauskiene 2016; Gunawan; Djajadikerta, Smith 2009];

- formularz ujawnień [Hendryk, Fit, Adamów [2018];

- wskaźniki opierające się na ankietach [Hoang, Abeysekera, Ma 2019; Helfaya, Whittibgton 2018];

- badania wydarzeń (event studies) [Karmańska, Łada 2019];

- indeksy zawartości [Helfaya, Whittington 2018]. 


\section{Raport zintegrowany jako kluczowa forma raportowania niefinansowego}

Instytucją zajmującą się raportowaniem zintegrowanym jest IIRC (International Integrated Reporting Council), która definiuje sprawozdawczość zintegrowaną jako „Zwięzły komunikat na temat strategii przedsiębiorstwa, ładu korporacyjnego, osiąganych efektów działalności gospodarczej oraz perspektyw rozwojowych, w kontekście środowiska zewnętrznego, które to elementy mają służyć kreowaniu wartości w krótkim, średnim i długim terminie" [IIRC 2013, s. 7].

Wydana przez IIRC w roku 2013 Struktura ramowa sprawozdawczości zintegrowanej uporządkowała treść raportu zintegrowanego. Wskazano w niej siedem zasadniczych elementów raportu, które mają zapewnić prezentację unikatowego dla każdej organizacji procesu kreowania wartości. Są to: profil organizacji i środowiska zewnętrznego, ład korporacyjny, model biznesowy, szanse i zagrożenia, strategia i alokacja zasobów, dokonania, podsumowanie wyników (perspektywy na przyszłość) [IIRC 2013, s. 24]. W dokumencie tym wskazano również trzy fundamentalne koncepcje, na których opiera się raportowanie zintegrowane: różnorodne kapitały (zasoby), jakie organizacja wykorzystuje w swojej działalności, model biznesowy realizowany przez daną organizację, kreowanie wartości w czasie. Podkreślono także, że sprawozdawczość zintegrowana ma się koncentrować wokół modelu biznesowego danej organizacji, jej zasobów i relacji, z których korzysta i które kształtuje, nazywanych, jak już wcześniej wspomniano, kapitałami.

Sprawozdawczość zintegrowana to raport holistyczny, mówiący o tworzeniu wartości. Ramy IR opierają się na szerokiej koncepcji integracji [Pistoni, Songini (red.) 2015]; i tak:

- wyniki przedsiębiorstwa interpretowane są jako wynik połączonego wykorzystania różnych rodzajów kapitału dostarczanych przez różnych interesariuszy: kapitał finansowy, ludzki, techniczny, intelektualny, społeczny i kapitał ekologiczny;

- ramy wymagają wyraźnego wskazania relacji między strategią firmy a jej wynikami;

- integracja jest również realizowana przez procesy i procedury organizacyjne;

- ramy promują zintegrowane myślenie i silną współpracę między funkcjami w celu poprawy tworzenia wartości przedsiębiorstw w dłuższej perspektywie;

- tworzona wartość jest nie tylko wynikiem wewnętrznych działań firmy, ale także jakości relacji z różnymi interesariuszami.

Jak przewiduje IIRC, sprawozdanie zintegrowane - pojedyncze sprawozdanie zawierające informacje niefinansowe i finansowe - stanie się zasadniczym sprawozdaniem danej organizacji, łączącym różne wątki sprawozdawczości w spójną, zintegrowaną całość [IIRC 2011].

Publikowanie sprawozdań zintegrowanych promuje większą przejrzystość organizacji przez dostarczanie informacji potrzebnych interesariuszom do oceny dłu- 
goterminowych perspektyw w jasnej i zwięzłej formie [García-Sánchez i in. 2013]. Ponadto rozwój sprawozdawczości zintegrowanej tworzy strategiczne narzędzia dla firm, które chcą skorelować wyniki finansowe z wynikami niefinansowymi [Dragu, Tudor-Tiron 2014] w celu legitymizacji i podniesienia swojej reputacji oraz zoptymalizowania [Frias-Aceituno i in. 2013; Dragu, Tudor-Tiron 2014].

Format sprawozdania zintegrowanego dopuszcza stosowanie nowoczesnych technologii i zachęca do tego, jako że zapewniają one uzyskanie dodatkowych i szczegółowych informacji na żądanie, np. przez umieszczenie linków do stron internetowych.

\section{Badania dotyczące sprawozdawczości zintegrowanej}

Badania nad sprawozdawczością zintegrowaną można podzielić na dwie grupy. Pierwsza obejmuje studia literaturowe na temat samej koncepcji sprawozdawczości zintegrowanej, a druga dotyczy praktyki sprawozdawczości zintegrowanej (por. [Bek-Gaik, Rymkiewicz 2016, s. 771] .

Poprzednie badania dotyczące raportów zintegrowanych skupiały się na analizie roli i celów raportów [Beattie, Smith 2013; Brown, Dillard 2014; Dumay i in. 2016; Lodhia 2014; Stacchezzini i in. 2016], a także relacji między IR i CSR [Sierra-García $i$ in. 2015]. Niedawno w literaturze podkreślono determinanty IR, koncentrując się na tym, dlaczego organizacje publikują raporty zintegrowane i jakie są czynniki wyjaśniające ich przyjęcie [Frias-Aceituno i in. 2013; Berg, Jensen 2012; van Bommel 2014; Rezaee 2016]. W innych badaniach przeanalizowano główne problemy związane z wdrażaniem IR na podstawie analizy studium przypadku [Burke, Clark 2016; Havlová 2015; Mio (red.) 2016]. Niektórzy autorzy podjęli się próby oceny jakości ujawnień w IR [de Villiers i in. 2014; de Villiers, Sharma 2017; Flower 2015; Morros 2016; Pistoni i in. 2018]. Literatura dotycząca oceny jakości IR jest dość ograniczona [Marx, Mohammadali-Haji 2014; Ruiz Lozano, Tirado-Valencia 2016].

W Polsce badań jest stosunkowo niewiele; dotyczą one głównie praktyki sporządzania sprawozdań zintegrowanych ${ }^{5}$. Mimo małej próby badawczej (bo tylko nieliczne polskie spółki sporządziły sprawozdania zintegrowane) wnioski z badań pokrywają się z wnioskami z badań zagranicznych (por. m.in. [Bek-Gaik, Rymkiewicz 2015; 2016; Garstecki 2015a; 2015b]).

Główne krytyczne kwestie dotyczące jakości IR podkreślone w literaturze to: brak łączności między strategią, modelem biznesowym, wynikami i przyszłymi prognozami ze względu na słaby przepływ narracji i ograniczone wykorzystanie schematów i map, obecność luki informacyjnej w obszarach, takich jak zarządza-

\footnotetext{
${ }^{4}$ Przegląd badań na temat sprawozdawczości zintegrowanej można znaleźć m.in. w [Bek-Gaik 2017].

${ }^{5}$ Należy podkreślić, że badania polskich autorów z zakresu jakości ujawnień niefinansowych dotyczyły głownie ujawnień CSR, por. m.in. [Fijałkowska, Macuda 2019; Hąbek 2018; Michalak 2018].
} 
nie, zaangażowanie interesariuszy i proces istotności, nieadekwatny opis modelu biznesowego i audytu wewnętrznego, niekompletność informacji i ograniczona weryfikacja stron trzecich [Eccles, Serafeim 2015]. Ponadto w niektórych badaniach podkreślono, że nawet jeśli firmy deklarują zastosowanie ram IR, to wdrażają je tylko częściowo. Badacze zaobserwowali również tendencję do słabego ujawniania procesu tworzenia wartości w organizacji i wskaźników dokonań/wyników działalności oraz dużą dowolność w kreowaniu informacji niefinansowych.

Ciekawe wyniki badań dotyczą jakości informacji niefinansowych. Pistoni i in. [2018] opracowali model punktacji i tablicę wyników IR (IRS), które zastosowano do analizy 116 zintegrowanych raportów wydanych w latach 2013 i 2014. Główne ustalenia wskazują, że jakość IR jest niska. Kiliç i Kuzey [2018] zbadali charakter i zakres ujawnień przyszłościowych we wczesnych przykładach sprawozdawczości zintegrowanej oraz determinanty takich ujawnień. Próba objęła 55 firm niefinansowych, których sprawozdania są dostępne w Bazie Danych Przykładów Sprawozdań Zintegrowanych za rok 2014. Indeks ujawnień przyszłościowych (FLDI) został podzielony na dwie główne grupy: wskaźniki ilościowe i jakościowe, obejmując łącznie 30 pozycji. Autorzy ustalili, że większość podmiotów wykazuje tendencję do dostarczania raczej jakościowych ujawnień dotyczących przyszłości niż ilościowych. Co więcej, wyniki pokazały, że zróżnicowanie pod względem płci i wielkości firmy są pozytywnie związane z ujawnieniami przyszłościowymi, podczas gdy dźwignia finansowa jest negatywnie powiązana $\mathrm{z}$ ujawnieniami perspektywicznymi (przyszłościowymi). Wbrew oczekiwaniom autorzy nie stwierdzili istotnego wpływu wielkości zarządu, składu zarządu, rentowności czy branży/sektora działalności na ujawnienia przyszłościowe.

\section{Praktyka raportowania zintegrowanego - ocena jakości ujawnień}

Celem badania była ocena jakości ujawnień w praktyce raportowania zintegrowanego polskich spółek w latach 2013-2017. Począwszy od roku 2013, liczba spółek publikujących IR rosła ${ }^{6}$. Większość badanych spółek przygotowywała swój raport zintegrowany w formie zarówno tradycyjnej, jak i interaktywnej. Łącznie poddano badaniu sporządzone w rozpatrywanym okresie raporty zintegrowane opracowane przez 20 spółek. Proces badawczy obejmował następujące etapy:

- identyfikacja spółek sporządzających raporty zintegrowane,

- ocena ilościowa i jakościowa ujawnień.

W badaniu sformułowano następujące pytania badawcze:

1. W jakiej formie spółki sporządzają sprawozdania zintegrowane?

2. Jak zmieniała się zawartość informacyjna raportów zintegrowanych?

3. Jak zmieniała się jakość poszczególnych ujawnień?

${ }^{6}$ Należy zauważyć, że rok 2013 nie był pierwszym rokiem, w którym spółki sporządzały raport zintegrowany - grupa Lotos opublikowała go już w 2009 roku, a KGHM Polska Miedź - w roku 2011. 
Zdefiniowano listę elementów podlegających ocenie ${ }^{7}$. We wstępnym przeglądzie oceniono następujące obszary (tab. 1):

- kontekst (informacje ogólne) IR,

- rzetelność i wiarygodność IR,

- formę prezentacji IR,

- treść IR.

Pierwszy z wymienionych obszarów (background area) ocenia, jaki tytuł nosi dokument oraz czy w dokumencie przedstawiono wprowadzenie poświęcone omówieniu takich zagadnień, jak:

- powody sporządzania raportu zintegrowanego,

- cele raportu zintegrowanego,

- odbiorcy raportu zintegrowanego,

- osoby odpowiedzialne za proces przygotowania raportowania zintegrowanego,

- zaangażowanie zarządzających w przygotowanie raportu,

- podstawy formalne sporządzania raportu (framework standards).

W kolejnym obszarze wiarygodności i rzetelności przeanalizowano, czy raport podlega weryfikacji przez wewnętrznego i zewnętrznego audytora, a także zwrócono uwagę na nagrody i wyróżnienia za jakość sporządzonego IR.

Kolejnym ocenianym aspektem była forma prezentacji sprawozdania IR, jaką przyjęła spółka.

Czwarty oceniany obszar dotyczy analizy treści IR pod kątem ich zgodności z wytycznymi opracowanymi przez IIRC - IR Framework (tab. 1). W obszarze treści przeanalizowano zgodność raportu z zaleceniami IR Framework, dotyczącymi takich elementów, jak: profil organizacji i otoczenia, model biznesowy, szanse i typy ryzyka, strategia i alokacja zasobów, ład organizacyjny, dokonania, perspektywy, podstawy prezentacji, a także rodzaje kapitałów organizacji oraz proces tworzenia wartości.

W celu oceny treści ujawnień przyjęto 6-stopniową skalę Likerta, na której 5 jest oceną najwyższą, a 0 oznacza, że element jest nieobecny w treści. Szczegółowa skala ocen przedstawia się następująco:

0 - element nieobecny w treści,

1 - element zawarty w treści, w bardzo niewielkim stopniu zgodny z zasadami IR,

2 - element zawarty w treści, opis bazuje na informacjach ilościowych, w niewielkim stopniu zgodny z zasadami IR,

3 - element zawarty w treści, opis zrównoważony, przeciętna ilość informacji zgodna z zasadami IR,

4 - element zawarty w treści, opis szczegółowy, w dużym stopniu zgodny z zasadami IR,

5 - element zawarty w treści, opis doskonały, prawie całkowicie zgodny z zasadami IR [Pistoni i in. 2018].

${ }^{7}$ Jako wzorzec przyjęto badanie, które wykonali A. Pistoni, L. Songini i F. Bavagnoli [2018] na próbie 59 spółek w latach 2013-2014. 
Tabela 1. Obszary, zmienne i atrybuty oceny jakości raportowania zintegrowanego

\begin{tabular}{|c|c|c|c|}
\hline \multicolumn{4}{|c|}{ Obszary raportowania zintegrowanego } \\
\hline $\begin{array}{c}\text { Kontekst } \\
\text { (Informacje ogólne) }\end{array}$ & $\begin{array}{c}\text { Rzetelność } \\
\text { i wiarygodność }\end{array}$ & $\begin{array}{c}\text { Forma } \\
\text { prezentacji }\end{array}$ & Treść \\
\hline \multicolumn{4}{|c|}{ Zmienne obszarów raportowania zintegrowanego } \\
\hline $\begin{array}{l}\text { - } \text { motywacje do wyboru } \\
\text { IR } \\
\text { - } \text { cele raportu IR } \\
\text { - } \text { beneficjenci raportu } \\
\text { osoba odpowiedzialna } \\
\text { za proces IR } \\
\text { - zaangażowanie zarządu } \\
\text { - tytuł raportu } \\
\text { - } \text { spójność IR } \\
\text { z ogólnie stosowanymi } \\
\text { standardami ujawnień }\end{array}$ & $\begin{array}{l}\text { - audyt } \\
\text { wewnętrzny } \\
\text { - weryfikacja } \\
\text { przez stronę } \\
\text { trzecią } \\
\text { - podziękowania } \\
\text { i nagrody za IR }\end{array}$ & $\begin{array}{l}\text { - zawiera } \\
\text { sprawozdanie } \\
\text { finansowe } \\
\text { - wersja } \\
\text { tradycyjna* } \\
\text { - wersja online }\end{array}$ & $\begin{array}{l}\text { - } \text { profil organizacji } \\
\text { i otoczenia } \\
\text { - } \text { model biznesowy } \\
\text { - } \text { szanse i ryzyka } \\
\text { - } \text { strategia i alokacja } \\
\text { zasobów } \\
\text { - ład organizacyjny } \\
\text { - dokonania } \\
\text { - perspektywy } \\
\text { - }{ }^{* * *} \\
\text { - kadstawa prezentacji } \\
\text { - } \text { proces tworzenia wartości }\end{array}$ \\
\hline \multicolumn{4}{|c|}{ Atrybuty oceny jakości zmiennych obszarów raportowania zintegrowanego } \\
\hline $\begin{array}{l}\text { - przyjęcie wytycznych } \\
\text { i standardów } \\
\text { raportowania } \\
\text { - jasne określenie wizji } \\
\text { przez zarząd }\end{array}$ & $\begin{array}{l}\text { - weryfikacja } \\
\text { przez stronę } \\
\text { trzecią } \\
\text { - osiągnięcie } \\
\text { nagród/ } \\
\text { wyróżnień }\end{array}$ & $\begin{array}{l}\text { - dostępność } \\
\text { dokumentu }\end{array}$ & $\begin{array}{l}\text { - ujawnienia ilościowe } \\
\text { - określenie celów } \\
\text { i raportowanie } \\
\text { odpowiednio do celów } \\
\text { - raportowanie } \\
\text { uwzględniające słabe } \\
\text { strony } \\
\text { - możliwość właściwej } \\
\text { oceny dokonań } \\
\text { na podstawie } \\
\text { prezentowanych ujawnień } \\
\text { przedstawianie istotnych } \\
\text { kwestii } \\
\text { raportowanie } \\
\text { znormalizowanych } \\
\text { danych }\end{array}$ \\
\hline
\end{tabular}

${ }^{*}$ Prezentacja $\mathrm{w}$ formie dokumentu pdf. ${ }^{* *}$ Prezentacja $\mathrm{w}$ formie interaktywnej. ${ }^{* * *}$ Perspektywy (outlook, ujawnienia przyszłościowe) stanowią informacje o wyzwaniach organizacji związanych z realizacją strategii oraz o potencjalnych skutkach tych wyzwań dla przyszłych wyników i modelu biznesowego.

Źródło: opracowanie własne na podstawie [Pistoni i in. 2018; Hammond, Miles 2004].

W przypadku trzech pozostałych obszarów - kontekstu, rzetelności i wiarygodności oraz formy - oceniano obecność lub brak każdej z proponowanych zmiennych. Wynik 0 przyznano w razie braku danego elementu, natomiast wynik 1 przypisano, jeśli element został uwzględniony w raporcie. 
Próba badawcza obejmuje 60 publikowanych raportów zintegrowanych, dotyczących lat 2013-2017 , sporządzanych przez 20 grup kapitałowych. Liczba raportów w poszczególnych latach zwiększała się stopniowo, ponieważ nie wszystkie podmioty sporządzały raporty zintegrowane za rok 2013 (tab. 2). W związku z tym możliwość porównań czasowych była ograniczona.

Tabela 2. Wykaz spółek uwzględnionych w badaniu

\begin{tabular}{|c|c|c|c|c|c|c|}
\hline Lp. & Spółka & 2013 & 2014 & 2015 & 2016 & 2017 \\
\hline & \multicolumn{6}{|l|}{\begin{tabular}{|l|} 
WIG20 \\
\end{tabular}} \\
\hline 1 & KGHM & + & + & + & + & + \\
\hline 2 & LOTOS & + & + & + & + & + \\
\hline 3 & LPP & $+*$ & $+*$ & $+*$ & $+*$ & + \\
\hline 4 & MBANK & $+*$ & $+*$ & $+*$ & $+*$ & + \\
\hline 5 & ORANGE PL & $+*$ & $+*$ & $+*$ & + & + \\
\hline 6 & PGE & $+*$ & $+*$ & + & + & + \\
\hline 7 & PKN ORLEN & $+*$ & + & + & + & + \\
\hline \multirow[t]{2}{*}{8} & TAURON PE & $+*$ & $+*$ & + & + & + \\
\hline & \multicolumn{6}{|l|}{ WIG30 } \\
\hline 9 & GRUPA AZOTY & + & + & + & + & + \\
\hline 10 & ING BSK & $+*$ & $+*$ & $+*$ & + & + \\
\hline \multirow[t]{2}{*}{11} & PKP CARGO & $+*$ & $+*$ & $+*$ & $+*$ & + \\
\hline & \multicolumn{6}{|l|}{ mWIG40 } \\
\hline 12 & BOGDANKA & $+*$ & + & + & + & + \\
\hline \multirow[t]{2}{*}{13} & BUDIMEX & $+*$ & $+*$ & $+*$ & + & + \\
\hline & \multicolumn{6}{|l|}{ Pozostale } \\
\hline 14 & ANG & + & + & + & + & + \\
\hline 15 & GAZ-SYSTEM & + & + & + & + & + \\
\hline 16 & GRUPA GPEC & $+*$ & $+*$ & + & + & + \\
\hline 17 & PELION & + & + & + & + & $+*$ \\
\hline 18 & ŚNIEŻKA & $+*$ & $+*$ & $+*$ & + & $+*$ \\
\hline 19 & PSE & $+*$ & $+*$ & $+*$ & $+*$ & + \\
\hline 20 & ERBUD & $+*$ & $+*$ & $+*$ & + & + \\
\hline
\end{tabular}

Oznaczenia: + raport zintegrowany; +* raport roczny.

Źródło: opracowanie własne.

${ }^{8}$ Wybrano lata 2013-2017, ponieważ w 2013 roku wydane zostały wytyczne IIRC. Można więc przypuszczać, że raporty publikowane od roku 2013 powinny być bardziej spójne z ramami IR, niż to miało miejsce w przeszłości. Wśród podmiotów objętych próbą są spółki działające w różnych branżach. 
W pierwszym etapie analizy oceniono całą próbę 60 raportów, aby uzyskać ogólny obraz zaawansowania jakości IR w odniesieniu do wyodrębnionych obszarów (tab. 3-4). Wyniki analizy wskazały, iż większość raportów uwzględnia wyodrębnione elementy. Tabela 3 prezentuje poziom zmiennych charakteryzujących badane raporty zintegrowane w układzie liczby obserwacji. W ogólnych założeniach wszystkie badane spółki wskazują odbiorców raportu, zaangażowanie zarządzających wskazuje $95 \%$ badanych podmiotów, a standardy sporządzania raportów - 93\% badanych dokumentów. Wyniki w obszarze kontekstu dowodzą, iż raportujący nie przywiązują większej uwagi do wskazania osób odpowiedzialnych za przygotowanie raportu (czyni tak tylko 60\% badanych), przyczyn sporządzania raportu (75\%) i celów raportu (87\%). Badając kwestię wiarygodności i rzetelności, można zaobserwować, że większość raportów została poddana audytowi wewnętrznemu (93\%), a znacznie mniej (43\%) poddano audytowi zewnętrznemu. Niewielka liczba raportów (13\%) otrzymała nagrody za jakość. Pod względem formy przeważa tradycyjna wersja sporządzania raportów (78\%), nieco mniejszy odsetek sporządzonych dokumentów (73\%) stanowią raporty dostępne w wersji online, natomiast około $60 \%$ raportów zawiera pełne sprawozdanie finansowe.

Tabela 3. Ocena zmiennych charakteryzujących raporty w układzie liczby obserwacji

\begin{tabular}{|l|c|c|c|c|c|c|}
\hline \multicolumn{1}{|c|}{ Wyszczególnienie } & Nie & $\%$ & Tak & $\%$ & $\begin{array}{c}\text { Liczba } \\
\text { obserwacji }\end{array}$ & $\%$ \\
\hline Zmienne & & & & & & \\
\hline Kontekst & & & & & & \\
\hline Powody publikacji & 20 & 33 & 40 & 67 & 60 & 100 \\
\hline Cele raportu & 8 & 13 & 52 & 87 & 60 & 100 \\
\hline Odbiorcy & 0 & 0 & 60 & 100 & 60 & 100 \\
\hline Osoby odpowiedzialne & 24 & 40 & 36 & 60 & 60 & 100 \\
\hline $\begin{array}{l}\text { Zaangażowanie } \\
\text { zarządzających }\end{array}$ & 3 & 5 & 57 & 95 & 60 & 100 \\
\hline $\begin{array}{l}\text { Standardy sporządzania } \\
\text { raportu }\end{array}$ & 4 & 7 & 56 & 93 & 60 & 100 \\
\hline $\begin{array}{l}\text { Wiarygodność } \\
\text { i rzetelność }\end{array}$ & & & & & & 100 \\
\hline Audyt wewnętrzny & 4 & 7 & 56 & 93 & 60 & 100 \\
\hline Audyt zewnętrzny & 34 & 57 & 26 & 43 & 60 & 100 \\
\hline Nagrody, podziękowania & 52 & 87 & 8 & 13 & 60 & 100 \\
\hline Cechy formalne & & & & & & 60 \\
\hline Sprawozdanie finansowe & 24 & 40 & 36 & 60 & 60 & 100 \\
\hline Wersja tradycyjna & 13 & 22 & 47 & 78 & 60 & 6000 \\
\hline Wersja online & 16 & 27 & 44 & 73 & 60 & \\
\hline
\end{tabular}

Źródło: opracowanie własne. 
Elementy treści raportu zintegrowanego oceniono (tab. 4) zgodnie z proponowanym systemem punktacji. W analizie zmiennych dotyczących treści raportów oceny mogą być bardziej subiektywne niż w kwestii kontekstu, formy oraz rzetelności i wiarygodności dokumentów, co wynika z szerszej skali punktacji. Ze względu na niewielką próbę badawczą nie dokonano statystycznej weryfikacji ocen poszczególnych zmiennych.

Tabela 4. Ocena częstotliwości występowania ocen poszczególnych zmiennych charakteryzujących raporty w układzie liczby obserwacji*

\begin{tabular}{|c|c|c|c|c|c|c|c|c|c|}
\hline \multirow{2}{*}{$\begin{array}{l}\text { Wyszcze- } \\
\text { gólnienie }\end{array}$} & \multicolumn{6}{|c|}{ Częstotliwość występowania ocen (\%) } & \multirow{2}{*}{$\begin{array}{l}\text { Średnia } \\
\text { ocen }\end{array}$} & \multirow{2}{*}{ Mediana } & \multirow{2}{*}{$\begin{array}{c}\text { Liczba } \\
\text { obserwacj }\end{array}$} \\
\hline & 0 & 1 & 2 & 3 & 4 & 5 & & & \\
\hline \multicolumn{10}{|l|}{ Zmienne } \\
\hline \multicolumn{10}{|l|}{ Treść } \\
\hline Profil i otoczenie & 0 & 0 & 7 & 17 & 47 & 30 & 4,00 & 4 & 60 \\
\hline $\begin{array}{l}\text { Model } \\
\text { biznesowy }\end{array}$ & 0 & 7 & 20 & 25 & 37 & 12 & 3,27 & 3 & 60 \\
\hline Szanse i ryzyka & 0 & 8 & 12 & 23 & 35 & 22 & 3,50 & 4 & 60 \\
\hline $\begin{array}{l}\text { Strategia/ } \\
\text { Alokacja } \\
\text { zasobów }\end{array}$ & 0 & 0 & 12 & 23 & 38 & 27 & 3,80 & 4 & 60 \\
\hline $\begin{array}{l}\text { Ład } \\
\text { korporacyjny }\end{array}$ & 0 & 8 & 13 & 37 & 27 & 15 & 3,27 & 3 & 60 \\
\hline Dokonania & 0 & 0 & 0 & 12 & 57 & 32 & 4,20 & 4 & 60 \\
\hline Perspektywy & 0 & 7 & 27 & 33 & 25 & 8 & 3,02 & 3 & 60 \\
\hline \begin{tabular}{|l|} 
Podstawy \\
formalne \\
prezentacji
\end{tabular} & 7 & 0 & 3 & 7 & 70 & 13 & 3,73 & 4 & 60 \\
\hline Kapitały & 3 & 17 & 37 & 12 & 17 & 15 & 2,67 & 2 & 60 \\
\hline $\begin{array}{l}\text { Proces tworzenia } \\
\text { wartości }\end{array}$ & 0 & 13 & 23 & 10 & 37 & 17 & 3,20 & 4 & 60 \\
\hline
\end{tabular}

* Objaśnienia: 0 - element nieobecny w treści; 1 - element zawarty w treści, w bardzo niewielkim stopniu zgodny z zasadami IR; 2 - element zawarty w treści, opis bazuje na informacjach ilościowych, w niewielkim stopniu zgodny z zasadami IR; 3 - element zawarty w treści, opis zrównoważony, przeciętna ilość informacji zgodna z zasadami IR; 4 - element zawarty w treści, opis szczegółowy, w dużym stopniu zgodny z zasadami IR; 5 - element zawarty w treści, opis doskonały, prawie całkowicie zgodny z zasadami IR.

Źródło: opracowanie własne.

Obszar treści wykazuje znaczne zróżnicowanie - dwie na dziesięć pozycji osiąga średni wynik wyższy od 4 lub równy tej wartości. Najbardziej szczegółowo i wyczerpująco opisane są w raportach dokonania oraz profil organizacji i jej otoczenie, 
natomiast najmniej dokładnie przedstawiono zasoby w ujęciu rodzajów kapitałów (średnia ocen 2,6), perspektyw (średnia ocen 3,02), procesu tworzenia wartości (średnia ocen 3,20), a także model biznesowy oraz ład korporacyjny (tab. 4). Wyniki te sugerują, że treść raportów zintegrowanych nadal wymaga dopracowania, zwłaszcza pod względem informacji niefinansowych.

Na podstawie uzyskanych wyników badań można stwierdzić, że jakość ujawnienia w obszarze treści nie jest zadowalająca, szczególnie w odniesieniu do ujawnień przyszłościowych oraz modelu biznesowego. Występuje także duże zróżnicowanie wyników między pojedynczymi pozycjami dotyczącymi treści raportów, a w szczególności niższą jakość wykazują innowacyjne elementy raportów, wprowadzone w wytycznych IIRC.

W kolejnym etapie badania przeanalizowano strukturę występowania zmiennych dotyczących kontekstu, rzetelności i wiarygodności raportów, a także cech formalnych w latach 2013-2017 (tab. 5). Porównanie w czasie obecności poszcze-

Tabela 5. Obecność zmiennych charakteryzujących raporty w układzie rocznym

\begin{tabular}{|l|r|r|r|r|r|r|r|r|r|r|}
\hline \multicolumn{1}{|c|}{ Wyszczególnienie } & \multicolumn{2}{|c|}{$\begin{array}{c}2013 \\
6 \text { raportów }\end{array}$} & \multicolumn{2}{c|}{$\begin{array}{c}2014 \\
\text { raportów }\end{array}$} & \multicolumn{2}{c|}{$\begin{array}{c}2015 \\
12 \text { raportów }\end{array}$} & \multicolumn{2}{c|}{$\begin{array}{c}2016 \\
16 \text { raportów }\end{array}$} & \multicolumn{2}{c|}{$\begin{array}{c}2017 \\
18 \text { raportów }\end{array}$} \\
\hline Zmienne & liczba & $\%$ & liczba & $\%$ & liczba & $\%$ & liczba & $\%$ & liczba & $\%$ \\
\hline Kontekst & & & & & & & & & & \\
\hline Powody publikacji & 2 & 33 & 6 & 75 & 9 & 75 & 9 & 56 & 14 & 78 \\
\hline Cele raportu & 6 & 100 & 8 & 100 & 10 & 83 & 12 & 75 & 16 & 89 \\
\hline Odbiorcy & 6 & 100 & 8 & 100 & 12 & 100 & 16 & 100 & 18 & 100 \\
\hline Osoby odpowiedzialne & 3 & 50 & 5 & 63 & 7 & 58 & 10 & 63 & 11 & 61 \\
\hline $\begin{array}{l}\text { Zaangażowanie } \\
\text { zarządzających }\end{array}$ & 6 & 100 & 6 & 75 & 12 & 100 & 15 & 94 & 18 & 100 \\
\hline $\begin{array}{l}\text { Standardy sporządzania } \\
\text { raportu }\end{array}$ & 6 & 100 & 8 & 100 & 11 & 92 & 14 & 88 & 17 & 94 \\
\hline $\begin{array}{l}\text { Wiarygodność } \\
\text { i rzetelność }\end{array}$ & & & & & & & & & & \\
\hline Audyt wewnętrzny & 6 & 100 & 7 & 88 & 11 & 92 & 15 & 94 & 17 & 94 \\
\hline Audyt zewnętrzny & 3 & 50 & 5 & 63 & 5 & 42 & 5 & 31 & 8 & 44 \\
\hline $\begin{array}{l}\text { Nagrody, } \\
\text { podziękowania }\end{array}$ & 2 & 33 & 2 & 25 & 0 & 0 & 2 & 13 & 2 & 11 \\
\hline Cechy formalne & & & & & & & & & & \\
\hline $\begin{array}{l}\text { Sprawozdanie } \\
\text { finansowe }\end{array}$ & 2 & 33 & 3 & 38 & 8 & 67 & 11 & 69 & 12 & 67 \\
\hline Wersja tradycyjna & 6 & 100 & 7 & 88 & 9 & 75 & 12 & 75 & 13 & 72 \\
\hline Wersja online & 4 & 67 & 6 & 75 & 9 & 7 & 12 & 75 & 13 & 72 \\
\hline
\end{tabular}

Źródło: opracowanie własne. 
gólnych zmiennych w raportach jest utrudnione ze względu na zwiększającą się liczbę publikowanych dokumentów o tym charakterze, dlatego badanie ma charakter poglądowy, a porównaniu poddano wartości względne, wyrażone wskaźnikami struktury. Informacje charakteryzujące odbiorców, poziom zaangażowania oraz audyt wewnętrzny raportów zintegrowanych ujawniane są w większości dokumentów w większym stopniu niż pozostałe elementy. Można przypuszczać, iż w odniesieniu do interesariuszy raportujący, zgodnie ze zintegrowanym podejściem, kierują się zasadą istotności i dokładnie wskazują odbiorców raportów zintegrowanych. Wysoki poziom wdrożenia wytycznych raportowania zintegrowanego $\mathrm{w}$ odniesieniu do interesariuszy może wskazywać, że organizacje uznają podejście interesariuszy za ważny składnik strategii firmy. Przeważająca część raportów nie jest poddawana audytowi zewnętrznemu i nie zawiera informacji o osobach odpowiedzialnych za przygotowanie tych dokumentów.

Obszar wiarygodności i rzetelności wykazuje wysoki udział sprawozdań poddanych audytowi wewnętrznemu, co dowodzi zastosowania dobrych praktyk wynikających z wytycznych IIRC. Rosnące zainteresowanie raportami przełożyło się niekiedy na przyznanie nagród za ich jakość.

Oceniając cechy formalne omawianych dokumentów, można stwierdzić, że coraz większy udział publikowanych raportów stanowią raporty w formie interaktywnej, zawierające linki do powiązanych informacji. W związku z tym zmniejsza się udział dokumentów zawierających sprawozdania finansowe w pełnej wersji.

Tabela 6. Średnie wartości każdej zmiennej treści raportu w układzie rocznym

\begin{tabular}{|l|c|c|c|c|c|c|}
\hline \multicolumn{1}{|c|}{ Zmienne } & 2013 & 2014 & 2015 & 2016 & 2017 & $\begin{array}{c}2017 / 2013 \\
\%\end{array}$ \\
\hline \multicolumn{1}{|c|}{ Treść } & & & & & & 6 \\
\hline Profil i otoczenie & 4,00 & 3,88 & 3,75 & 4,00 & 4,22 & 51 \\
\hline Model biznesowy & 2,50 & 3,00 & 2,92 & 3,38 & 3,78 & 24 \\
\hline Szanse i ryzyka & 3,00 & 3,38 & 3,58 & 3,44 & 3,72 & 44 \\
\hline Strategia/alokacja zasobów & 3,00 & 3,38 & 3,67 & 3,81 & 4,33 & 0 \\
\hline Lad korporacyjny & 3,33 & 3,63 & 2,92 & 3,25 & 3,33 & 13 \\
\hline Dokonania & 3,83 & 4,38 & 4,08 & 4,19 & 4,33 & 20 \\
\hline Perspektywy & 2,83 & 2,88 & 2,75 & 2,94 & 3,39 & 1 \\
\hline $\begin{array}{l}\text { Podstawy formalne } \\
\text { prezentacji }\end{array}$ & 3,83 & 3,88 & 3,58 & 3,56 & 3,89 & 46 \\
\hline Kapitały & 2,17 & 1,63 & 2,50 & 2,94 & 3,17 & 14 \\
\hline Proces tworzenia wartości & 3,17 & 2,63 & 2,75 & 3,38 & 3,61 & \\
\hline
\end{tabular}

Źródło: opracowanie własne. 
Średnie oceny elementów obszaru treści raportów (tab. 6) wskazują, iż wyniki prawie wszystkich pozycji (z wyjątkiem ładu korporacyjnego) są wyższe w roku 2017 niż w roku 2013. Znacznie lepiej przygotowano w badanych dokumentach informacje dotyczące takich kwestii, jak: model biznesowy, wyodrębnienie kapitałów, strategia/alokacja zasobów. Istotne są także wzrost jakości w ujawnianiu szans i typów ryzyka oraz pojawienie się w ostatnich latach (choć tylko w kilku raportach) wyodrębnionych informacji przyszłościowych jako perspektyw rozwoju organizacji. Poddane badaniu raporty systematycznie są wzbogacane także informacjami dotyczącymi procesu tworzenia wartości.

Oceniając jakość treści raportów z perspektywy roku 2017, można stwierdzić, że większość innowacyjnych kwestii, których ujawnienie jest wymagane przez wytyczne IIRC, takich jak perspektywy, model biznesowy, kapitały, szanse i typy ryzyka czy proces tworzenia wartości, wciąż wymaga poprawy. Mimo poprawy w stosunku do początkowego okresu analizy średni poziom ujawnień tych zagadnień w roku 2017 kształtuje się poniżej 4. Za pozycje dosyć dobrze prezentowane w raportach zintegrowanych można uznać dokonania oraz profil organizacji i jej otoczenie średnia ocena ujawnień tych elementów kształtuje się powyżej 4.

\section{Wnioski}

Uzyskane wyniki badań odzwierciedlają pozytywne zmiany w odniesieniu do zarówno liczby publikowanych raportów, jak i jakości niektórych obszarów ujawnień w publikowanych raportach. Należy jednak podkreślić, że poziom ujawnień nie jest w pełni zadowalający. Poprawy i udoskonalenia wymagają przede wszystkim takie elementy raportowania, jak model biznesowy, outlook, informacje o tworzeniu wartości i prezentacja zasobów jednostki zgodnie z wytycznymi IIRC. Lepsza jakość charakteryzuje aspekty tradycyjnie ujawniane przez organizacje, takie jak dokonania, profil organizacji i otoczenie. Przygotowując raporty zintegrowane, organizacje koncentrują się w pierwszej kolejności na sposobie i formie prezentacji informacji, a dopiero później - na jakości treści.

Jedną z przyczyn niewielkiej liczby raportów zintegrowanych i ich średniej jakości mogą być wysokie koszty poniesione na ich przygotowanie, nieprzekładające się na adekwatne korzyści, w związku z czym raporty sporządzane są częściej przez duże grupy kapitałowe. Równocześnie ograniczony zakres ujawnień w raportach zintegrowanych może wynikać z obawy, że informacje te są istotne dla konkurentów i ich nieujawnianie stanowi podstawę przewagi konkurencyjnej organizacji. Również w odniesieniu do prezentacji negatywnych wyników organizacji pojawiają się obawy o możliwą reakcję rynków finansowych i zainteresowanych stron.

Analiza raportów pozwala stwierdzić, iż w początkowych latach podmioty raportujące w mniejszym stopniu kierowały się wytycznymi IIRC i przyjmowały własne rozwiązania. Obecnie organizacje coraz częściej stosują wytyczne IIRC, co z pewnością wpływa na uporządkowanie treści raportu i jakość analizy danych. 
Przeprowadzone badanie pozwoliło na określenie krytycznych aspektów związanych z jakością raportów zintegrowanych. W ograniczonym zakresie prezentowane są w nich ujawnienia przyszłościowe, jednak na przestrzeni lat proporcja ujawnień dotyczących przyszłości do ujawnień przeszłościowych stopniowo się zwiększa. $\mathrm{W}$ początkowym okresie $\mathrm{w}$ niewielkiej liczbie raportów zastosowano podejście kapitałowe podczas prezentowania zasobów wykorzystywanych przez organizacje $\mathrm{w}$ ich działalności, ale obserwowane jest przechodzenie $\mathrm{w}$ kierunku ujawniania sześciu kluczowych kapitałów wymienianych jako kluczowe kapitały w modelu biznesu. Ze względu na ograniczoną zawartość ujawnień przyszłościowych wydaje się, że raportowanie zintegrowane nie wnosi wartości dodanej do dotychczasowej sprawozdawczości, choć zdaniem autorek raport zintegrowany powinien być niezbędnym elementem raportowania i biorąc pod uwagę bardzo rozbudowaną obecnie sprawozdawczość organizacji, powinien on stanowić kompendium zawierające wiele informacji prezentowanych aktualnie w różnych innych raportach.

\section{Literatura}

Alshikhi O., Abdullah B., 2018, Information quality: Definitions, measurement, dimensions, and relationship with decision making, European Journal of Business and Innovation Research, vol. 6, no. 5 , s. 36-42.

Beattie V., McInnes B., Fearnley S., 2004, A Methodology for analysing and evaluating narratives in annual reports: A comprehensive descriptive profile and metrics for disclosure quality attributes, Accounting Forum, vol. 28, no. 3, s. 205-236.

Beattie V., Smith S. J., 2013, Value creation and business models: Refocusing the intellectual capital debate, British Accounting Review, vol. 45 (4), s. 243-254.

Bek-Gaik B., 2015, Sprawozdawczość zintegrowana - wybrane problemy, Zeszyty Naukowe Uniwersytetu Szczecińskiego. Finanse, Rynki Finansowe, Ubezpieczenia, nr 77, s. 479-491.

Bek-Gaik B., 2017, Sprawozdawczość zintegrowana - przeglad badań, Zeszyty Teoretyczne Rachunkowości, nr 92, s. 9-29.

Bek-Gaik B., Rymkiewicz B., 2015, Sprawozdawczość zintegrowana w praktyce polskich spótek gietdowych, [w:] Micherda B. (red.), Sprawozdawczość i rewizja finansowa: uwarunkowania ekonomiczne, społeczne i regulacyjne, Kraków, Wydawnictwo Uniwersytetu Ekonomicznego, s. 60-83.

Bek-Gaik B., Rymkiewicz B., 2016, Tendencje rozwoju sprawozdawczości zintegrowanej w praktyce polskich spółek giełdowych, Zeszyty Naukowe Uniwersytetu Szczecińskiego. Finanse, Rynki Finansowe, Ubezpieczenia, nr 1 (79), s.767-785.

Berg N., Jensen J.C., 2012, Determinants of traditional sustainability reporting versus integrated reporting. An institutionalist approach, Business Strategy and the Environment, no. 21, s. 299-316.

Bovee M., Srivastava R., Mark B., 2003, A conceptual framework and belief-function approach to assessing overall information quality, International Journal of Intelligent Systems, vol. 18, no. 1, s. 51-74.

Brown J., Dillard J., 2014, Integrated reporting: On the need for broadening out and opening up, Accounting, Auditing \& Accountability Journal, vol. 27, issue 7, s. 1120-1156.

Burke J., Clark C., 2016, The business case for integrated reporting: Insights from leading practitioners, regulators, and academics, Business Horizons, vol. 59, issue 3, s. 273-283.

Chakroun, Hussainey, 2014, Disclosure quality in Tunisian annual reports, Corporate Ownership \& Control, vol. 11, issue 4, s. 58-80. 
Climate change and sustainability. How sustainability has expanded the CFO's role, 2011, Ernst \& Young, http://www.ey.com/US/en/Services/Specialty-Services/Climate-Change-and-Sustainability-Services/How-sustainability-hasexpanded-the-CFOs-role.

Czajor P., Michalak M., 2016, Jakość ujawnień dotyczacych zobowiąań finansowych w sprawozdaniach finansowych spótek indeksu WIG 30, Finanse, Rynki Finansowe, Ubezpieczenia nr 2 (80), cz. 2, s. 431-438.

De Villiers C., Low M., Samkin G., 2014, The institutionalisation of mining company sustainability disclosures, Journal of Cleaner Production, no. 84, s. 51-58.

De Villiers C., Sharma U., 2017, A critical reflection on the future of financial, intellectual capital, sustainability and integrated reporting, Critical Perspectives on Accounting, w druku.

Dey C., Burns J., 2010, Integrated reporting at novo nordisk, [w:] Accounting for Sustainability: Practical Insights, A.Hopwood, J. Unerman, J. Fries (red.), London, Earthscan, s. 197-214.

Dragu I., Tudor-Tiron A., 2013, New corporate reporting trends. Analysis on the evolution of integrated reporting, Annals of the University of Oradea, Economic Science Series, vol. 22, issue 1, s. 1221$-1228$.

Dragu I., Tudor-Tiron A., 2014, Research agenda on integrated reporting: New emergent theory and practice. Emerging markets queries in finance and business, Procedia Economics and Finance, no. 15, s. $221-227$.

Dumay J., 2016, A critical reflection on the future of intellectual capital: from reporting to disclosure, Journal of Intellectual Capital, vol. 17, issue 1, s. 168-184.

Dumay J., Bernardi C., Guthrie J., Demartini P., 2016, Integrated reporting: A structured literature review, Accounting Forum, vol. 40, issue 3, s. 166-185.

Dyduch J., 2018, Methods of measurement of CSR disclosure level in corporate reporting, Prace Naukowe Uniwersytetu Ekonomicznego we Wrocławiu, nr 520, s. 46-53.

Dyrektywa 2014/95/UE zmieniająca dyrektywę 2013/34/UE w odniesieniu do ujawniania informacji niefinansowych i informacji dotyczących różnorodności przez niektóre duże spółki oraz grupy.

Eccles R., Krzus M.P., Tapscott D., 2010, One Report: Integrated Reporting for a Sustainable Strategy, 1 st edition, Wiley Publisher.

Eccles R., Saltzman D., 2011, Achieving sustainability through integrated reporting, Stanford Social Innovation Review, vol. 9, no. 3, s. 56-61.

Eccles R., Serafeim G., 2015, Corporate and Integrated Reporting: A Functional Perspective, [w:] Corporate Stewardship: Achieving Sustainable Effectiveness, red. E. Lawler, S. Mohrman, J. O'Toole, Greenleaf.

Elshandidy T., Neri L., Guo Y., 2018, Determinants and impacts of risk disclosure quality: Evidence from China, Journal of Applied Accounting Research, Forthcoming, https://ssrn.com/abstract=3206228 or http://dx.doi.org/10.2139/ssrn.3206228.

Fijałkowska J., Macuda M., 2019, CSR Reporting Practices in Poland, [w:] Corporate Social Responsibility in Poland, red. A. Długopolska-Mikonowicz, S. Przytuła, C. Stehr, https://link.springer. com/chapter/10.1007/978-3-030-00440-8_13.

Flower J., 2015, The international integrated reporting council: A story of failure, Critical Perspectives on Accounting, no. 27, s. 1-17.

Frias-Aceituno J.V., Rodríguez-Ariza L., García-Sanchez I.M., 2013, Is integrated reporting determined by a country's legal system? An exploratory study, Journal of Cleaner Production, vol. 44, s. $45-55$.

García-Sánchez I.M., Rodríguez-Ariza L., Frías-Aceituno J.V., 2013, The cultural system and integrated reporting, International Business Review, no. 22, s. 828-838.

García-Sánchez I.M., Hussain N., Martínez-Ferrero J., Ruiz-Barbadillo E., 2019, Impact of disclosure and assurance quality of corporate sustainability reports on access to finance, Corporate Social Responsibility and Environmental Management, vol. 26, s. 832-848. 
Gerwanski J., Kordsachia O., Velte P., 2019, Determinants of materiality disclosure quality in integrated reporting: Empirical evidence from an international setting, Business Strategy and the Environment, 28, s. 750-770.

Gunawan J., Djajadikerta H., Smith M., 2009, An examination of corporate social disclosures in the annual reports of indonesianlisted companies, Ecu Publication Pre.

Gustavsson M., Wänström C., 2009, Assessing information quality in manufacturing planning and control processes, International Journal of Quality \& Reliability Management, vol. 26 no. 4, s. 325-340.

Hammond K., Miles S., 2004, Assessing quality assessment of corporate social reporting: UK perspectives, Accounting Forum, no. 28, s. 61-79.

Havlová K., 2015, What integrated reporting changed: The case study of early adopters, Business Economics and Management 2015 Conference, BEM2015, Procedia Economics and Finance, no. 34, s. 231-237.

Hąbek P., 2018, Sprawozdawczość przedsiębiorstw w zakresie ich społecznej odpowiedzialności. Ocena jakości raportów CSR, CeDeWu, Warszawa.

Helfaya A., Whittington M., 2018, Does designing environmental sustainability disclosure quality measures make a difference?, Business Strategy and the Environment, vol. 28, issue 4, s. 525-541.

Helfert M., Foley O., Ge M., Cappiello C., 2009, Analysing the effect of security on information quality dimensions, ECIS 2009 - 17th European Conference on Information Systems.

Hendryk M., Fit M., Adamów A., 2018, Analiza ujawnień w zakresie rzeczowych aktywów trwałych na podstawie sprawozdań finansowych spółek z sektora ,,budownictwo” za lata 2015 i 2016, Studia i Prace Kolegium Zarządzania i Finansów, nr 163, s. 165-181.

Hoang T.C., Abeysekera I., Ma S., 2019, Earnings quality and corporate social disclosure: The moderating role of state and foreign ownership in Vietnamese listed firms, Emerging Markets Finance \& Trade, vol. 55, s. 272-288,

IASB, 2018, Conceptual Framework for Financial Reporting, IFRS Foundation, http://eifrs.ifrs.org/ eifrs/PdfAlone?id=21922\&sidebarOption=UnaccompaniedConceptual (16.02.2019).

IIRC, 2011, Towards Integrated Reporting - Communicating Value in the 21st Century, http://integratedreporting.org/wp-content/uploads/2011/09/IR-Discussion-Paper-2011_spreads.pdf (20.12.2014).

IIRC, 2013, The International <IR> Framework, http://www.theiirc.org/wp-content/uploads/2013/ 12/13-12-08-THE-INTERNATIONAL-IR-FRAMEWORK-2-1.pdf (20.11.2015).

ISO, 2000, 1994, Quality Management and Quality Assurance. Vocabulary. ISO 84021994. International Organization for Standardization.

Kabalski P., 2005, Nadrzędne zasady przygotowania i prezentacji sprawozdań finansowych, Przegląd Podatkowy, $\mathrm{nr} 1$.

Kahn B., Strong D., Wang R., 2002, Information quality benchmarks: Product and service performance, Communications of The ACM, vol. 45, no. 4, 184-192.

Karmańska A., 2014, The imperative of sustainable growth and reporting integration: Three eras in the corporate reporting development, Copernican Journal of Finance \& Accounting vol. 3, no. 1, s. 73-82.

Karmańska A., Łada M., 2019, Ujawnianie obszarów i czynników ryzyka w sprawozdaniach z dziatalności spótek giełdowych - obserwacje wobec zmian regulacji prawnych, Zeszyty Teoretyczne Rachunkowości, tom 103 (159), s. 39-61.

Katmon N., Mohamad Z., Norwani N., Farooque O., 2018, Comprehensive board diversity and quality of corporate social responsibility disclosure: Evidence from an emerging market, Journal of Business Ethics, 157(4), s. 447-481.

Kazirod A., 2002, Rola rewizji sprawozdań finansowych, Nasz Rynek Kapitałowy, nr 2.

Kędzierska-Bujak I., 2013, Rola informacji dostarczanych przez rachunkowość w systemach motywacyjnych - wybrane zagadnienia, [w:] Nauka rachunkowości u progu gospodarki opartej na wiedzy, red. A. Karmańska, Szkoła Główna Handlowa w Warszawie, Warszawa. 
Krasodomska J., 2012, Zintegrowana sprawozdawczość spółek w 2020 roku, Zeszyty Teoretyczne Rachunkowości, tom 66 (122), SKwP, s. 101-110.

Krasodomska J., 2014, Informacje niefinansowe w sprawozdawczości spółek, Wydawnictwo Uniwersytetu Ekonomicznego w Krakowie, Kraków.

Leitoniene S., Sapkauskiene A., 2016, Information disclosure in corporate social responsibility reports. The case of Lithuanian companies, Zeszyty Teoretyczne Rachunkowości, tom 88 (144), s. 73-85.

Leopizzi R., Iazzi A., Venturelli A., Principale S., 2019, Nonfinancial risk disclosure: The "state of the art" of Italian companies, Corporate Social Responsibility and Environmental Management, vol. 26, s. 1-11.

Li S., Liu C., 2018, Quality of corporate social responsibility disclosure and cost of equity capital: Lessons from China, Emerging Markets Finance \& Trade, vol. 54, s. 2472-2494.

Lodhia S., 2014, Why do companies not produce sustainability reports?, Social and Environmental Accountability Journal, vol. 34 (2), s. 124-124.

Marcinkowska M., 2006, Ewolucja raportu: jak zaprezentować wartość przedsiębiorstwa, czyli o nowych tendencjach w sprawozdawczości biznesowej (cz. I), Nasz Rynek Kapitałowy, nr 4, s. 40-44.

Maroun W., Solomon J., 2012, Integrated Reporting: The Influence of King III on Social, Ethical and Environmental Reporting, The Association of Chartered Certified Accountants, London, http:// www.accaglobal.com/content/dam/acca/global/PDF-technical/integratedreporting/tech-tp-iirsa. pdf (18.05.2015).

Marx B., Mohammadali-Haji A., 2014, Emerging trends in reporting: An analysis of integrated reporting practices by South African top 40 listed companies, Journal of Economic and Financial Sciences, vol. 7, no. 1, s. 231-250.

Michalak J., 2018, Metody pomiaru i determinanty jakości informacji w raportach spółek giełdowych, Wydawnictwo Uniwersytetu Łódzkiego, Łódź.

Michalczuk G., 2009, Komunikowanie na temat kapitału intelektualnego wyzwaniem dla polityki informacyjnej spótek, Prace i Materiały Wydziału Zarządzania Uniwersytetu Gdańskiego, nr 1, s. 291-300.

Michalczuk G., Mikulska T., 2014, Sprawozdanie zintegrowane jako produkt finalny rachunkowości społecznej, Zeszyty Naukowe Uniwersytetu Szczecińskiego, nr 827. Finanse, Rynki Finansowe, Ubezpieczenia, nr 69, s. 197-207.

Mio C. (red.), 2016, Integrated Reporting, a new Accounting Disclosure, Palgrave MacMillan, UK.

Morros J., 2016, The integrated reporting: A presentation of the current state of art and aspects of integrated reporting that need further development, Intangible Capital, vol. 12, no. 1, s. 336-356.

Mućko P., 2018, Jakość sprawozdań narracyjnych i jej determinanty - przegląd literatury, Studia i Prace Kolegium Zarządzania i Finansów, Szkoła Główna Handlowa, zeszyt 165, s. 155-170.

Mućko P., Hońko S., 2013, „Sprawozdanie z działalności” - raport z pogranicza rachunkowości, Rachunkowość, nr 10.

Pistoni A., Songini L. (red.), 2015, Sustainability disclosure: State of the art and new directions, Book Series: Studies in Managerial and Financial Accounting, vol. 30.

Pistoni A., Songini L., Bavagnoli F., 2018, Integrated reporting quality: An empirical analysis, Corporate Social Responsibility and Environmental Management, no. 25, s. 489-507.

Rensburg R., Botha E., 2014, Is integrated reporting the silver bullet of financial communication? A stakeholder perspective from South Africa, Public Relations Review, vol. 40, s. 44-152.

Rezaee Z., 2016, Business sustainability research: A theoretical and integrated perspective, Journal of Accounting Literature, vol. 36, issue C, s. 48-64.

Roszkowska P., 2008, Wiarygodność raportów społecznej odpowiedzialności biznesu w kontekście relacji inwestorskich, e-Finanse, $\mathrm{nr} 4$.

Ruiz-Lozano M., Tirado-Valencia P., 2016, Do industrial companies respond to the guiding principles of the Integrated Reporting framework? A preliminary study on the first companies joined to the 
initiative, Revista de Contabilidad - Spanish Accounting Review, Elsevier, vol. 19 (2), s. 252-260, DOI: $10.1016 /$ j.rcsar.2016.02.001.

Samelak J., 2013, Zintegrowane sprawozdanie przedsiębiorstwa społecznie odpowiedzialnego, Wydawnictwo Uniwersytetu Ekonomicznego w Poznaniu, Poznań.

Sierra-Garcia L., Zorio-Grima A., Garcia-Benau M.A., 2013, Stakeholder engagement, corporate social responsibility and integrated reporting: An exploratory study, Corporate Social Responsibility and Environmental Management, no. 22, s. 286-304.

Sobczyk M., 2012, Zintegrowane raportowanie - nowy model raportowania biznesowego, Przedsiębiorczość i Zarządzanie, tom XIII, nr 1, s. 155-170.

Stacchezzini R., Melloni G., Lai A., 2016, Sustainability management and reporting: The role of integrated reporting for communicating corporate sustainability management, Journal of Cleaner Production, vol. 136, part A, s. 102-110.

Stępień M., 2010, Interakcja gospodarki i środowiska w rachunkowości jednostki gospodarczej, Zeszyty Naukowe, Uniwersytet Ekonomiczny w Krakowie, nr 816, s. 163-176.

Stubbs W., Higgins C., 2014, Integrated reporting and internal mechanisms of change, Accounting, Auditing \& Accountability Journal, vol. 27, issue 7, s. 1068-1089.

Szadziewska A., 2013, Rola rachunkowości w pomiarze efektywności działań CSR, Prace i Materiały Wydziału Zarządzania Uniwersytetu Gdańskiego, nr 4, s. 257-277.

Świderska G., 2007, W poszukiwaniu optymalnego raportu, Kwartalnik Nauk o Przedsiębiorstwie, nr 1, s. 15-23.

Świderska G.K., Bek-Gaik B., 2016, Dokąd zmierza raportowanie biznesowe?, Studia Ekonomiczne. Zeszyty Naukowe Uniwersytetu Ekonomicznego w Katowicach, nr 274, s. 7-16.

van Bommel K., 2014, Towards a legitimate compromise?: An exploration of integrated reporting in the Netherlands, Accounting, Auditing \& Accountability Journal, vol. 27, no. 7, s. 1157-1189.

Walińska E., 2015, Zintegrowany raport - poczatek końca sprawozdania finansowego?, Zeszyty Teoretyczne Rachunkowości, tom 82 (138), s. 151-165.

Walińska E., Bek-Gaik B., Gad J., 2016, Sprawozdawczość finansowa i niefinansowa przedsiębiorstwa - w kierunku integracji, Wydawnictwo Uniwersytetu Łódzkiego, Łódź.

Walińska E., Bek-Gaik B., Gad J., Rymkiewicz B., 2015, Sprawozdawczość przedsiębiorstwa jako narzędzie komunikacji z otoczeniem. Wymiar finansowy i niefinansowy, Wydawnictwo Uniwersytetu Łódzkiego, Łódź.

Wang R., Strong D., 1996, Beyond accuracy: What data quality means to data consumers, Journal of Management Information Systems, vol. 12, no. 4, s. 5-33.

Wasilewska E., 2010, Raportowanie spoleczne przedsiębiorstw: koncepcja i rola międzynarodowych standardów raportowania, Master of Business Administration, nr 4 (105), s. 93-104.

Wrona S., 2009, Sprawozdawczość biznesowa jako narzędzie komunikacji z inwestorami, Zeszyty Naukowe Uniwersytetu Szczecińskiego. Ekonomiczne Problemy Usług, nr 559 (42), s. 490-499. 